\author{
Михаил Вайскопф \\ Еврейский университет в Иерусалиме \\ michweisskopf@gmail.com
}

Michael Weisskopf

Hebrew University of Jerusalem

michweisskopf@gmail.com

\title{
РИХАРД ВАГНЕР, ФРАНЦ КАФКА И АЛЕКСАНДР ГРИН: К ИСТОРИИ ОДНОГО ЛИБРЕТТО
}

\section{RICHARD WAGNER, FRANZ KAFKA AND ALEXANDER GRIN: TOWARDS THE HISTORY OF ONE LIBRETTO}

Версия легенды о Летучем Голландце, вместе с «кроваво-красными парусами» морехода подсказанная композитору прозой Гейне, претворилась у него в бессвязный набор разнородных религиозно-романтических клише, осложненный вдобавок театральными штампами. Объединял эту эклектику лишь позднеромантический пафос всеобщей гибели, пропитавший либретто. Чуждый печально-ироническому гейневскому претексту, но сквозной для мировоззрения Вагнера, он окрасил его агрессивную публицистику и при ее посредстве нашел впоследствии практическую реализацию в годы нацизма. Своего злосчастного морехода Гейне сравнивал с Вечным Жидом - Агасфером, причем этот аллегорический персонаж имел у него также национально-автобиографический подтекст. В автокомментариях к опере Вагнер позаимствовал гейневское сопоставление - но одновременно в своем памфлете «Еврейство в музыке» использовал фигуру Агасфера в антисемитских целях и призвал к его уничтожению. Вместе с тем в XX веке как либретто, так и рассказ Гейне трансформировались у Кафки в новеллу «Охотник Гракх», тоже носившую автобиографический характер. С другой стороны, вагнеровская опера нашла контрастно-позитивное решение в феерии Александра Грина Aльlе паруса, где, среди прочего, изначально «кроваво-красные паруса» Гейне и Вагнера получили новый оттенок и иной, солярно-оптимистический смысл.

Ключевые слова: Летучий Голландец, Гейне, Агасфер, Кафка, Ленау, Erlösung, Маркс, Грин, мореплаватель, охотник.

A legend of the Flying Dutchman was suggested to Wagner by Heine's prose, along with the "blood-red sails" of the mariner. The composer turned it into an incoherent set of heterogeneous religious, Romantic, and theatrical cliches. This eclecticism was united only by the late Romantic cult of death and extermination which permeated the libretto. It was alien to Heine's sad irony of, but quite typical of Wagner's worldview. This cult of death gave a gloomy shade to the composer's aggressive journalism which was later absorbed by the German Nazism as a leading ideology, eventually practically implemented. Heine com- 
pared his ill-fated mariner with the Wandering Jew, that is, Ahasuerus: he saw in this allegorical character his own national and personal prototype. In the auto-commentaries to the opera, Wagner borrowed Heine's identification with the character, which did not prevent him from using Ahasuerus as an anti-Semitic gollywog in his pamphlet against Jewishness in music, calling for his destruction. In the XX century, both Wagner's libretto and Heine's story were transformed by Kafka into the novella "The Hunter Gracchus" that also had an autobiographical component. On the other hand, the plot of Wagner's opera found, by contrast, an optimistic solution in Alexander Grin's story Scarlet Sails, where Heine's and Wagner's initially "blood-red sails" acquired a new shade with a different, solar, that is, lifeasserting connotation.

Keywords: Flying Dutchman, Heine, Ahasuerus, Kafka, Lenau, Erlösung, Marx, Grin, mariner, hunter.

Публикуемые заметки ответвились от эссе, заказанного мне организаторами Вагнеровского фестиваля в Байройте. Речь шла о «Летучем Голландце» - ранней опере Вагнера, созданной им в 1841-м в Париже и без особого успеха поставленной в Дрездене на новый 1843 год. Сам он называл eе, правда, «музыкальной драмой». Композитор, претендовавший также на лавры поэта, сочинил к ней либретто. О его тексте мне и предложили написать - с учетом моей специализации в качестве русского филолога (безнадежно далекой, впрочем, от музыковедения). Я от души благодарен госпоже Елене Верес, инициировавшей это приглашение и на протяжении работы для Байройта оказывавшей мне самоотверженную поддержку, особенно весомую с учетом того, что наше время не благоприятствует библиотечным разысканиям. Г-жа Верес щедро помогала мне ценными советами и поправками, снабдила меня своим собственным, исключительно точным подстрочником ${ }^{1}$ и релевантной музыковедческой информацией, отобрав ее из необозримой библиографии по Вагнеру. Здесь я, однако, позволю себе существенно отойти от первоначально-байройтовской темы, сосредоточившись вслед за ней на некоторых ее перипетиях в минувшем столетии. Получился своего рода триптих.

1.

В целом вагнеровский текст опирается на знаменитую легенду XVIXVII вв., впервые напечатанную лишь накануне XIX столетия и воодушевившую романтиков - Колриджа, Гауфа, Гейне. Однажды, во время страшных штормов, голландский капитан, жестокосердый грешник и богохульник, бросил вызов самому дьяволу. Он поклялся обогнуть мыс Доброй Надежды (либо мыс Горн), даже если ему придется плыть до Судного дня, — и тогда с неба раздался глас: «Да будет так: плыви!» Иногда рассказывали, что раз в десять лет Голландцу позволяется сойти на берег, чтобы найти ту, которая захочет выйти за него замуж и разделить его судьбу.

У Вагнера прототипический сюжет попал в сбивчивую зависимость от актуальных влияний. В предисловии к своей книге Myзыкальные дpaмы

1 Оттуда я беру и все последующие русские цитаты из либретто. 
Рихарда Вагнера К. Дальхауз упоминает «неопределенную эклектику 1830 -х гг.», отличавшую тягу его соотечественников к «романтической опере» в традиции Э. Т. А. Гофмана, Вебера и Маршнера; при этом сама немецкая опера оставалась слабой. В 1839-м, спасаясь и от кредиторов, и от рутинного прозябания, Вагнер через Лондон бежит из Риги в Париж, эту «столицу девятнадцатого столетия» (Dahlhaus 1979: 2-3), где ему тоже суждено будет испытать, однако, тягостное чувство невостребованности.

В либретто написанной там программной оперы, — «Летучий Голландец», - он никуда не уйдет от привычной эклектики, а лишь усугубит ее. Несмотря на свои новаторские претензии, Вагнер попросту стянет здесь воедино разнородные тенденции, осложнив их добавочными несуразицами. Склейку катализирует, в сущности, как раз осуждавшаяся им французская общекультурная ситуация тех лет, в которой тоже господствовала позднеромантическая эклектика, только несравненно более размашистая, чем в Германии, — «неистовая» эклектика помпезно-мелодраматического, развлекательного и авантюрно-исторического толка.

Многократно говорилось, что образчик для «музыкальной драмы» Вагнеру дал знаменитый парижский эмигрант Генрих Гейне - точнее, его повесть 1834 - года «Из мемуаров господина фон Шнабелевопского» (см. хотя бы Dahlhaus 1979: 7-10) или, еще точнее, ее вставной сюжет. К концу 6-й главы странствующий гейневский нарратор вспоминает, как «однажды ночью увидел проходивший мимо большой корабль с распущенными кроваво-красными парусами, походивший на темного великана в широком огненно-красном плаще. Был ли это Летучий Голландец?» А следующую главу он открывает самой легендой, слышанной им еще в детстве. Десятилетние матримониальные испытания Летучего Голландца мемуарист сжимает до семилетних, а его надежды на верную супругу преподносит с сарказмом: «Бедный Голландец! Он частенько радуется, избавившись от брака и своей избавительницы, и возвращается снова на борт корабля».

По прибытии в Амстердам рассказчик якобы увидел там пьесу о Голландце. Действие ее происходит в Шотландии. Алчный купец заочно сватает богатому мореходу свою дочь Катарину. Дома у них на стене висит портрет красивого и «опасного» моряка, каким он запечатлен был «сто лет назад», — и с тех пор из рода в род переходит «предостережение, по которому женщины из этой семьи должны опасаться оригинала». Трепещущая невеста сразу узнает гостя - а тот, иронизируя, старается сперва развеять ее страхи, но потом все же рассказывает о своей горестной судьбе в третьем лице, что не скрывает истину от Катарины. На его вопрос о будущей супружеской верности она отвечает: «Верна до смерти!» Но как раз в этот момент описание спектакля у мемуариста прерывается картиной его собственных эротических злоключений с некоей «голландской Мессалиной», начавшихся прямо в театре и еще более настраивающих его на скептический лад. Затем он все же снова посещает театр и узнает завершение пьесы: «Супруг любит героиню, но хочет покинуть, чтобы избавить от гибели, 
и открывает ей свою ужасную судьбу и тяготеющее над ним страшное проклятие», - и тогда «верная жена бросается в море, и вот наступает конец проклятью <...> он спасен, и мы видим, как корабль-призрак погружается в морскую пучину». Глава подытожена моралью мемуариста, комически предостерегающего женщин от летучих голландцев, а мужчин — от самих женщин, которые «даже при самых благоприятных обстоятельствах» несут им гибель (Гейне 1958: 442-446).

Через семь лет именно эта версия легенды была утилизована композитором - с сомнительного согласия автора (Dahlhaus 1979: 9-10) — вместе с кроваво-красными парусами и семилетними интервалами. Заемному сюжету Вагнер придаст, однако, надрывное разрешение. По язвительному выражению Э. Ньюмэна, «здоровый цинизм» Гейне, «с улыбкой взирающего на сентиментальную развязку», Вагнер вытеснит «тевтонской серьезностью» и «твердым убеждением, что в конце оперы «он сообщает нам нечто доброе и полезное для наших душ» (Newman 1925: 18-19).

Итак, по пути домой судно норвежца Даланда укрылось от яростного шторма в скалистой бухте - куда под своими кроваво-красными парусами врывается и корабль Летучего Голландца. Из его исповедальной арии мы узнаем, что «пречистый Ангел Господень» открыл ему условия спасения но, увы, они недостижимы, и страдалец помышляет о гибели всего мира и о своей собственной, о переходе «в Ничто» — «in Nichts vergehn!» Тем не менее в последующем диалоге с Даландом он просит у него приюта, предлагая ему взамен свои несметные богатства, - ведь он все еще жаждет обрести наконец родину и по-настоящему верную жену. Позарившись на его сокровища, норвежец незамедлительно обещает выдать за него свое «верное дитя» - Сенту. Мощный ветер устремляет оба корабля к близкой гавани.

Пока что в доме Даланда девушки, ожидая его возвращения, поют за прялками, но взор Сенты, как всегда, прикован к портрету, запечатлевшему какого-то бледного и угрюмого моряка, т. е. самого Голландца. Его историю очень давно поведала ей Мари, кормилица, которая теперь, однако, бранит непослушную Сенту: «Ты всю свою молодую жизнь промечтаешь перед лживым изображением?» Подтрунивая над нею, девушки говорят, что беззаветно влюбленный в нее охотник Эрик «подстрелит в гневе соперника со стены!» Тогда она поет им ту балладу о вечно странствующем корабле, которую так часто певала ей неосмотрительная Мари. Оказывается, каждые семь лет его капитан выходит на берег, дабы отыскать ту поистине верную подругу, что избавит его от мучений, - но всякий раз терпит неудачу. Девушки потрясены, а сама Сента клянется: «Это я, я спасу его своей верностью! Пусть Ангел Господень меня ему покажет!» Клятва ужасает вошедшего Эрика, и он рассказывает ей о своем страшном сне: с чужого корабля спускаются Даланд и тот самый незнакомец с портрета, а Сента бросается им навстречу, чтобы обнять его. На тревожные вопросы Эрика об уже назначенном с нею бракосочетании она отвечает уклончиво. 
Охотник в смятении выбегает - а его сон тут же сбывается: в дом входят Даланд с Голландцем. Потрясенная Сента мгновенно узнает оригинал, а гость чувствует, что это именно та, кого он так долго искал.

Следует праздник вернувшихся домой норвежских матросов и, отдельно, беснование голландских мертвецов, - под их дикое пение и раскаты чудовищной бури, вселяющих ужас в мирных норвежцев. Ошеломленный же Эрик, узнав о назначенной помолвке, понапрасну напоминает возлюбленной о ее былых объятьях и горестно уличает ее в неверности. Между тем Голландец, случайно услышав его попреки, скоропалительно заключает, что он ошибся и в Сенте, как во всех ее предшественницах. Навсегда изверившись в Боге, он возвращается на свой корабль под кроваво-красными парусами - но тут Сента воочию доказывает ему свою верность, бросившись со скалы в море. «В то же мгновенье корабль Голландца распадается на обломки (вместе с экипажем, конечно). Вдали из воды поднимаются Голландец и Сента, оба преображенные, он обнимает ее».

В черновике, как установил Х. С. Чемберлен (Чемберлен 2016: 396, прим. 2), вагнеровская драма разыгрывалась тоже в Шотландии - хотя биограф-антисемит, вскользь отметивший этот гейневский след, предусмотрительно забывает о самом Гейне. Потом композитор предпочел Норвегию, сообразно переделав имена персонажей.

Ближайшая память фарсового жанра оставила у него непреднамеренные семантические и мотивные лакуны, разъедавшие текст и интриговавшие комментаторов. Некоторые нестыковки давно перечислил Э. Ньюмэн в своей книге «Вагнер как человек и художник»: «В умах критиков всегда была неразбериха по поводу того, поклялась ли Сента в своей любви Эрику, или нет; а совершенно ясно, что все прочтение ее характера и мотивов в последнем акте зависит от ответа на этот вопрос $<. . .>$ Эрик вообще слишком бледная фигура, а Даланд просто «оперный отец» в чистом виде. Я и сам никогда не мог понять, как это может быть, чтобы Сента, только взглянув на Голландца, сразу узнала в нем оригинал портрета, висящего у них дома, а отец ее не замечает никакого сходства, хотя Голландец при первой встрече поведал ему и о своей несчастной судьбе, и о своем желании найти женщину, которая его полюбит. И, наконец, мне всегда хотелось бы знать, что случилось с командой корабля Голландца, когда Сента бросается в море, и корабль тонет со всеми матросами». Вместе с тем комизм ситуации не ощущался самим Вагнером ввиду отсутствию у него чувства юмора и самоиронии, несовместимой с его мессианским нарциссизмом. Все же он задним числом ссылался в свое оправдание на музыкально-метафизический субстрат, который якобы сам по себе сшивает происходящее на сцене (оправдания, подхваченные впоследствии Томасом Манном): «В “Летучем Голландце" я прежде всего старался дать действие в его простейших чертах, исключить ненужные детали...» пишет в «Музыке будущего» в 1861 Вагнер (1978: 525). Увы, главной из них оказался здравый смысл, потребный и в минималистских пределах оперных жанров, пусть даже притяза- 
ющих на новаторство. В этом смысле «Летучий Голландец» послужил заставкой ко всей истории его житейского и теоретического сумбура.

Вероятно, излишним было бы напоминать здесь, что излюбленным героем романтики был - и навсегда остался, при всех ее сегодняшних модификациях, — человек, духовно либо физически отторгнутый или же сам отторгшийся от постылой земли - т. е. моряк, путешественник, одинокий воитель, охотник, скиталец, бродяга. В раннем и высоком романтизме ему соответствовала героиня, пассивно ожидающая еще неведомого ей, как правило, суженого на берегу - в прямом или, гораздо чаще, переносном смысле. Оба они, по существу, чужды нашему убогому бытию, по слову Лермонтова в «Демоне»: «Господь из лучшего эфира Соткал живые струны их. Они не созданы для мира И мир был создан Не для них» (подробней обо всем этом: Вайскопф 2012).

В традиционном раскладе преобладающие, хотя и не обязательные, приметы обоих — томная худоба, вдохновенный взор и бледность - подспудно указывают на их потустороннее происхождение и, по сути дела, роднят с мертвецами. Распространенной кульминацией их первой встречи было взаимное узнавание (память душ), усвоенное и преемниками романтизма наподобие Достоевского вместе с сонмом других авторов. В то же время герой почти ех officio соотносился с Иисусом, а его возлюбленная с нежной и попечительной Мадонной (в силу кое-каких богословских парадоксов латентно связанной со Спасителем брачными узами). При случае эти привязки слегка камуфлировалась метафорическим псевдонимом ангел, относимым то к одному, то к другому партнеру.

При более витальной обрисовке героя его странствия - прослеживаемые к античному эпосу — сочетают в себе байроническую тягу к экзотике (горы, дальние страны и пр.) с влечением к бурям (лермонтовский «Парус»). Романтик бросает им вызов, который знаменует его готовность к героическому преодолению бытия или к метафизической бесконечности. Такой типаж, давно доминировавший в западной авантюрной словесности, в николаевской России был пока довольно редок, но его метафизическая компонента акцентирована, например, у Теплякова, талантливого поэта 1830-х гг.:

Матрос! Что вдалеке твой взор распознает?

Что с мачты видишь ты? — Я вижу бесконечность!

Неудивительно, что и Вагнер в своем «Произведении искусства будущего» $(1849$, изд. 1850) превозносит романтические штормы и испытания, взыскуемые дерзновенным человеческим естеством (Вагнер 1978: 180-181) (понятым у него тогда еще по Фейербаху). Здесь композитора вдохновляли уже не депрессивные страдальцы вроде Голландца, а иные герои, захваченные неутолимым жизнелюбием, страстью к приключениям и всеядной любознательностью. Вместе с тем подобная версия selige Sehnsucht решительно противостояла старой церковной аллегорике, тоже помянутой Вагнером 
и живописующей плавание души по бурному морю страстей к спасительной гавани - Небесной родине, она же загробная Земля Обетованная.

При положительно-эротическом настрое сюжета романтическая беспредельность достигала, однако, счастливого предела - земного адеквата небесного отечества, - вне зависимости от того, бежал ли герой от любви или, казалось бы, в нее больше не верил. Как морское, так и прочие странствия - либо даже внешне бесцельное перемещение, - венчались встречей с заветной подругой, чей облик уже смутно предугадывался его душой. Олицетворяемый героиней приют заменит ему Небесную пристань, а обретенная возлюбленная Невесту Христову (= метафорический «ангел»). В принципе, однако, романтик мог вместе с нею вернуться к захватывающим путешествиям как адеквату духовного восхождения - и именно такое решение мы найдем в «Алых парусах» Грина, о которых речь пойдет ниже. В любом случае его маршрутом управляет таинственный магический зов - песня, музыка - и / или некая потусторонняя сила, маскируемая под случайность и порой олицетворяемая полуволшебным помощником. Все вместе заменяет либо дополняет для него ветер, несущий в себе семантику «духа Божия», но в иных, негативных изводах темы не лишенный и демонологических коннотаций. Бывают, конечно, и разочарования, вызванные мотивом соблазна, неверности либо неодолимых социальных барьеров, - и тогда сюжет смещается в мартирологическое русло.

Вагнер, как мы видели, развертывает в либретто другой, но смежный и тоже адаптированный романтизмом нарратив, попутно прихватывая иные фабульные мотивы, слабо увязываемые с центральным действием. По облику (бледность и пр.) романтических антигероев типа Голландца легко спутать с безвинными страдальцами, если б не «огненный взгляд» и кое-какие добавочные приметы, в отдаленной ретроспективе роднящие их с мятежным Люцифером. За ту или иную вину преступник, подобно своим земным предшественникам - Каину, Пилату или Агасферу осужден на изнурительно-безостановочное движение и мечтает лишь о прощении и покое (правда, в лице Байрона, весьма почитаемого композитором, эпатажный романтизм восславил и неукротимых богоборцев). У сюжета есть как положительные, так и отрицательные трактовки, и вторые по возможности подтягиваются к первым, хотя оптимистическая перспектива предусматривалась далеко не всегда. Заслуженно претерпеваемые грешником страдания парадоксально ориентируют его собственный образ тоже на Иисуса - как на парадигматического мученика, - хотя по понятным причинам сходство не акцентируется. Более того, и гонимым злодеям (а порой - просто безумцам) зачастую тоже приходит на помощь заместительница попечительной Мадонны - влюбленная девушка, готовая ради них к благородному самопожертвованию².

2 Имелся, впрочем, и популярный симметрический ход, заданный евангельским прецедентом с блудницей и отозвавшийся в ориенталистской окраске у Гете: это «Бог 
Теоретически тут допустима определенная конвергенция нарративов о любви, мечтательном страннике, безвинном страдальце и наказанном преступнике. Вагнер же склеил и тем самым деформировал эти варианты, а для технической мотивировки действия ввел в него инородные жанровые ходы, не слишком озаботившись согласованием целого.

Романтический ветер, приведший героя к Сенте, - отнюдь не веянье благого Духа. Направляясь домой — уже вместе с Голландцем, — капитан Даланд говорит, что попутный штормовый ветер «дует из чертовой дыры» и что тот, «кто полагается на ветер, полагается на милость Сатаны». Зато страшная команда призраков радуется этому вихрю, наполняющему их кроваво-красные паруса: «Хахаха! .... Сам Сатана нам их надувает!» Именно с ним отождествляет Голландца и охотник Эрик, силясь отговорить любимую от союза с пришельцем: «Ты в когтях Сатаны!» Действительно, хотя никакого особой вины, кроме вызова, — причем, брошенного им вовсе не Богу, а именно дьяволу, - за ним тут не числится, «черный капитан» (как называет Голландца его команда) и сам отнюдь не лишен бесовской окраски - на то он, собственно, и ходячий, вернее, плавающий мертвец. Чело его «помрачают муки» — характерный для романтизма реликт Каиновой печати. Заимствованный из Гейне портрет, с детства околдовавший героиню («мерзкий портрет», «лживое изображение» по гневному определению встревоженной кормилицы), тоже, вопреки претексту, получает в либретто отчетливо инфернальный привкус, скоординированный, как указывалось в литературе, с общеизвестной англо-готической традицией.

Клишированно романтическая бледность Сенты, оставаясь намеком на ее потустороннее происхождение, на сей раз сама по себе сближает ее с мертвенным Голландцем: так от метафизического канона Вагнер на балладный манер перескакивает к некрофилии, игнорируя принципиальное различие между двумя типажами - неотмирного возлюбленного и бодрствующего трупа. Межжанровый и межмотивный хаос захватывает и прочие фрагменты либретто. С одной стороны, моряк одержим понятной ностальгией, с другой, - для него пригодна любая «родина». Не имея ничего общего с церковным раем как чаемой гаванью мучеников, она, однако, поставлена в ассоциативное родство с ним: «Здесь он нашел родину, здесь его корабль в надежном порту!» — ликует девушка. Сообразно аллюзионно-романтической традиции, хотя тут и не слишком уместной, инфернальный мореход одновременно ассоциируется с Иисусом, возопившим с креста: «Боже мой, Боже Мой! для чего Ты Меня оставил?» (Мф. 27: 46). Вагнеровский грешник тоже горестно взывает к «ангелам, что оставили меня когда-то», - очевидно, к тем самым, которые воплотятся теперь в Сенте. Мариологически-попечительный мотив примет в ее лице направление, да-

и баядера» (1798) - вещь, оказавшая сильное влияние на романтические сюжеты о спасении падшей женской души; упоминает ее и Вагнер в своей книге 1851 года Onера и драма. Случалось, правда, что доверчивая грешница сама становилась жертвой бесчеловечного обмана и надругательства. 
лекое от гейневского претекста. У Вагнера сострадание героини явственно отдает поэтикой pieta или же духовным опытом визионеров: «Он стоит предо мной, - восклицает девушка, — с полными страдания очами, он выказывает мне свою неслыханную скорбь». Но перед нами лишь очередной инерционный реликт, пустой отголосок романтико-лирической схемы.

На первый взгляд, «томление» и «боль», жгущие грудь Сенты, и есть «любовь ангела», заменившего Голландцу именно того «пречистого Ангела Господня», что открыл ему «условия спасения». Однако сакрализованная эротика романтизма без остатка поглощается искомой «верностью» (весьма парадоксально звучавшей в устах Вагнера), а влюбленная дева заменена девушкой-смертью, идеально достойной суженого, который тоскует только по своей полноценной гибели (Dahlhaus 1979: 11-12). В конечном счете их брачный союз смахивает на хэппи энд в морге.

Подобно самому Спасителю, Сента решительно победила Сатану, ибо на ее некрофильский подвиг либреттист просто перенес ликование ап. Павла: «Смерть! где твое жало? ад! где твоя победа?» (I Кор. 15: 55). Ср. у Вагнера: «Обещала она тебе поругание, ад, своею верностью!» Однако эта ее мнимая победа над смертью достигается посредством уже иной - абсолютно беспросветной смерти, заменившей для обоих Царство Небесное. Через много лет в автокомментариях Вагнер сошлется на то же самое послание точнее, на Гимн любви из его 13 главы, который, наряду с Песнью Песней и вслед за церковью, романтики давно приспособили к своей псевдохристианской эротике. Но если в «Песни Песней» (8: 6) сказано, что «крепка, как смерть, любовь», то у Вагнера, как подчеркивает Дальхауз, это просто одно и то же. Свою беззаветную героиню композитор торжественно назовет «Женщиной Будущего» (Newman 1925: 21). Укажем и на другую, очень важную антитезу мировоззренческого порядка: вожделенная для прежних романтиков бесконечность заменена кончиной.

В глубинах романтической поэтики обычно мерцала непостижимая тайна - зловещая или, напротив, благостная. У Вагнера же метафизический иррационализм вытесняется нечаянным абсурдизмом - побочным продуктом не столько гейневской травестии, сколько его собственного вдохновения. Изначально напрашивался так и оставшийся неразрешимым вопрос, почему каждое семилетие все без исключения женщины изменяли мистическому мореходу и какими его персональными свойствами обусловлена эта рутина? Теперь, однако, по условиям вагнеровской фабулы ему предстоит с молниеносной быстротой обрести целительную альтернативу отсюда и вещий курьез, который мы находим в песне Сенты, подхваченной растроганными девушками: «Молите небо, чтобы скорее жена верность ему сохранила!»

Легенда о грешнике, приговоренном к невыносимому бессмертию (ср. булгаковского Пилата), странно контаминирована у Вагнера с обычным романтическим взаимоузнаванием влюбленных. Пускай Сента сходу узнает оригинал того портрета, который по какой-то непостижимой причине 
ее навсегда заворожил, - труднее понять реакцию самого оригинала. Почему он сам мгновенно узнает героиню, хотя прежде никогда ее не видел?

Как будто из дали давно минувших времен

Говорит со мной образ этой девушки:

Как я мечтал о ней страшную вечность назад, -

Так она стоит сейчас перед моими глазами здесь.

В сущности, перед нами и здесь эклектический казус. Ведь в поэтике романтизма взаимоузнавание молчаливо подразумевает, что влюбленные, изнывающие ныне в земном плену, обретались некогда в ином, горнем мире. Их любовь - это и есть обоюдное припоминание былого потустороннего союза, изначального родства либо андрогинного двуединства душ, поданного в ауре тайны. Однако все это не имеет касательства к вагнеровскому Голландцу, который из недр своей «страшной вечности» тоскует вовсе не по какому-то утраченному раю, а, напротив, по «вечному уничтожению» — по блаженному «Ничто». Заемная метафизика гностически-платоновского толка использована не по назначению - лишь как рудиментарный отросток романтического сюжетного организма.

Мистический рассказ о предреченной еще на небесах встрече вступает в жанровый и логический конфликт с избитой историей о влюбленных, разлучаемых «оперным отцом», по определению Ньюмэна (либо матерью, опекуном и т. д.). Двоится и образ героини. Охотник Эрик, ее прежний возлюбленный, резонно опасается, что жадный Даланд с ее согласия предпочтет ему богача - а уклончивая реакция девушки только подтверждает эти подозрения. Ее ответ вообще отдает двуличием: «Я еще дитя и не знаю, что пою... Ты боишься песни, портрета?» В последующем разговоре с самим Голландцем Сента с кротким лицемерием ссылается прежде всего на свою покорность родительской воле: «Какой бы жребий ни был мне назначен, Послушна всегда буду я отцу!»

Охотник предлагает ей свое сердце, «верное до смерти», - но, как мы знаем, эта «верность до смерти» получит у Сенты существенно иной смысл. Так раздваивается один и тот же ценностный мотив. Когда его страшный сон сбывается, Эрик с негодованием напоминает ей, что она поклялась ему в «вечной верности», - но героиня вновь имитирует удивление: «Я? В вечной верности тебе клялась?» За ее репликой просвечивает чисто формальная мотивировка измены: ведь она все же не приносила ему клятвы именно в «вечной» верности. Зато их неправильно понятые Голландцем пререкания используются, посредством неуклюжего qui pro quo, в качестве триггера. Потрясенный услышанным, он приходит к горестному выводу о неверности и этой своей суженой, на которую возлагал было надежду о спасении. Тем не менее по отношению к ней он гуманно ссылается на аналогичный юридический резон: «Ты верность обещала мне, но перед Вечным еще не клялась, это спасает тебя! Ведь знай, несчастная, какая судьба Достается той, которая нарушает верность мне: Вечное прокля- 
тие - ее жребий. Бессчетные жертвы подпали под этот приговор» (непонятно, опять-таки, вынесенный Богом или же Сатаной; но, как и в остальных случаях, это различие несущественно). Сента, однако, сразу опровергает его укоризны делом: следует суицидальный хэппи энд.

До того, как перейти к нему, не помешает вернуться к той самой сцене, где в беседе с Голландцем отец девушки зарится на несметные богатства, которыми гружен его корабль:

Редчайшие сокровища ты увидишь: -

Драгоценный жемчуг, благородные камни, -

и корыстолюбивый Даланд тут же предлагает ему в жены свою дочь, заодно ее рекламируя:

Ты даешь драгоценности, бесценные жемчуга -

Но высшее сокровище - верная жена...

В Евангелии с драгоценной жемчужиной сравнивается Царство Небесное Мф. 13: 45-46), отвергнутое у Вагнера. Для его эклектики показательно, с другой стороны, и ассоциативное соединение этого мотива с противоположным по духу ветхозаветным стихом, очень важным для немецкопротестантской домостроительной традиции - но столь же несовместимым с вагнеровской некрофилией:

Кто найдет жену доблестную? Цена ее выше жемчугов. (Притч. 31: 10), - а рядом, в ст. 14, упомянуты и корабли, с которыми сопоставлена эта наилучшая жена: «Она, как купеческие корабли, издалека добывает хлеб свой». Хотя эти цитатные реминисценции указывает на инерционную зависимость Вагнера от обоих Заветов, его Голландец с самого начала мечтает лишь о прекращении любого бытия:

День Суда! Судный день!

Когда наступишь ты в моей ночи?

Когда он грозно прозвучит, удар уничтожения, которым мир разрушится? -

и ему вторит команда Голландца: «Вечное уничтожение, возьми нас!» Для пресловутого вагнеровского «инстинкта смерти» (Г. Киршнер и др.) страдания героя - только один из предлогов, который сменит потом череда разномастных - от шопенгауэровских и буддистских до католических и германско-мифологических - мотивировок. В частности, согласно Вагнеру, именно потому, что настоящая любовь является наивысшим идеалом земной жизни, ей просто не место в ее пределах, и она достигается смертью, блаженством «вечного трансцедентального покоя». Разумеется, правы все те, кто говорит о его спонтанном схождении с Шопенгауэром, при знакомстве с которым - только в 1854 году, через много лет после «Голланд- 
ца» - он испытал радость встречи и задним числом нашел у него философскую санкцию для своего глобального пессимизма. Но у обоих этот настрой — как, кстати, впоследствии и у Э. фон Хартмана — был обусловлен соответствующей константой немецкого романтизма (имеющей, впрочем, и более глубокие корни), — константой, означенной уже у Новалиса с его некрофильскими «Гимнами к ночи».

Тем не менее греза о «вечном уничтожении», т. е. об истреблении всего человечества с упоением манифестируется как раз на излете романтизма. Ею одержим был, в частности, юный сатанист и поздний романтик Карл Маркс, проклинавший Бога, а в своей стихотворной драме 1837 года «Оуланем» (магически инвертированный Эммануэль) мечтавший, чтобы все бытие погрузилось «навеки в Ничто». Сатанистом был и его будущий оппонент - неистовый разрушитель Бакунин, дрезденский наставник и друг Вагнера (Вагнер 2001: 728-734).

Эсхатологический пафос сгустился также в продукции позднего русского романтизма, одним из главных представителей которого был именно Бакунин. Его кровожадно-революционные лозунги - это литургическое «смертью смерть поправ», пропущенное через левое гегельянство. Воля к смерти - без надежды на загробное воздаяние — нагнеталась как у Лермонтова, так и у авторов помельче: «Могилы жажду я! Прошу одной могилы!..» (Е. Бернет); «Мы дружно будем жить в могиле под крестом...» (С. Хитрово). Долгожданную кончину они тоже, причем еще до Вагнера, увязывали с вожделенной гибелью самой вселенной. Чтобы убедиться в этом, достаточно сравнить речения его Голландца:

Когда он грозно прозвучит, удар уничтожения, Которым мир разрушится?

Миры, закончите ваш бег!

Вечное [= навечное] уничтожение, возьми меня! -

с еще более помпезной продукцией А. Мейснера (1836), точно так же томившегося не только по своей собственной, но и по всеобщей смерти:

Померкни же, солнца нерадостный свет,

Сплетитеся в узел, орбиты планет.

Столпитесь, миры, в необъемлемый шар

И с треском родите всемирный пожар,

Чтоб рухнул вселенной безмерный колосс -

И смертному счастие отдал хаос!

(Вайскопф 2012: 62, 77-79, 83)

У Маркса и, в меньшей мере, у Бакунина суицидально-истребительная мания выльется в тотальное уничтожение «старого мира». Рихард Вагнер направит ее в сторону геноцида. 
Здесь я позволю себе вернуться к повести Гейне - к тому ее пассажу, где злосчастный мореход, тщетно маскируясь перед героиней, «смеется над суеверием, издевается над Летучим Голландцем, Вечным Жидом океана».

Однако, непроизвольно впадая в печальный тон, он рассказывает, какие несказанные муки пришлось претерпеть мингееру: среди безбрежной водной пустыни, говорит он, плоть его - не что иное, как гроб, в котором тоскует душа; его гонит от себя жизнь и не принимает смерть; подобно пустой бочке, которую волны кидают друг другу и снова насмешливо отбрасывают, мечется бедный голландец между жизнью и смертью, и ни та, ни другая не хотят его принять; его скорбь глубока, как море, по которому он плавает; на корабле его нет якоря, а в сердце - надежды» (Гейне 1958: 444).

Само собой, специфическая смесь иронии с патетикой чрезвычайно показательна для Гейне. И все же этот эпизодический для него образ исполнен как национальной, так и сопряженной с нею индивидуальной символики, понятной каждому, кто знаком с биографией автора, с его размышлениями о судьбах гонимого еврейства и с его собственной неприкаянностью в немецкой культуре.

Как в «Автобиографическом очерке» 1843-го года, так и в 1851 в «Обращении к моим друзьям», Вагнер со ссылкой на Гейне тоже назовет своего Голландца «Агасфером океана» - но во втором случае, подчеркивает Дальхаус (Dahlhaus 1979: 9), источником своего вдохновения он уже выставит якобы всего лишь пересказанный Гейне сюжет мифической «голландской пьесы». Осенью 1850 г., он уже успел напечатать свой печально знаменитый манифест «Еврейство в музыке», который переиздаст отдельной брошюрой в 1869-м. Так Вагнер стал главным апостолом антисемитизма в культуре и официальной музой нацизма. Среди всего прочего, он с запозданием обрушился и на Гейне (не слишком отступая, впрочем, от давних и повсеместных в Германии инвектив того же сорта).

Конечно, опера «Летучий Голландец» была создана в его, так сказать, еще донацистский период. Но уже там просквозили искры инфернального предвидения. Я имею в виду слово Erlösung, вызволение, — то, о котором мечтает Голландец и которое он отождествляет для себя с великим Ничто. В другом значении — уже в качестве «окончательного решения» еврейского вопроса - оно появится в антисемитском памфлете Вагнера: «Die Erlösung Ahasvers — der Untergang!», «Спасение Агасфера — в его погибели!»³

3 Заслуживает внимания совпадение его вывода с заключительным вердиктом Маркса из его статьи 1844 года «К еврейскому вопросу» (она войдет в нацистский сборник «Евреи свидетельствуют о самих себе»): «Die gesellschaftliche Emanzipation des Juden ist die Emanzipation der Gesellschaft vom Juden» - «Общественная эмансипация еврея есть эмансипация общества от еврейства». Насколько мне известно, вопрос о возможном влиянии этой публикации на Вагнера никем еще не затрагивался. 
В 1881-м он потребовал «насильственного устранения евреев из жизни Германии и Европы», на полвека с лишним упредив, как отмечают, гитлеровскую речь в рейхстаге от 30 января 1939 года. Не знаю, напрямую ли позаимствовал фюрер у этого безгранично почитаемого им «пророка национал-социализма» сам термин Erlösung, или же обошелся без этого содействия, но для миллионов европейских евреев он обернулась вагнеровским Ничто.

\section{2.}

Обратимся, однако, к менее мрачным отголоскам «Летучего Голландца». Странно препарированная Вагнером тема, очевидно, инспирировала у читателей желание перестроить ее по-своему и по-иному расставить ключевые фигуры. Яркий пример тому — краткая новелла Кафки «Охотник Гракх».

Преследуя серну в родном Шварцвальде, охотник упал в пропасть и погиб. Однако его «челн смерти» случайно взял неверный курс - и с тех пор ни в чем не повинный скиталец на протяжении столетий никак не может подняться в потусторонний мир. О своих посмертных злоключениях он рассказывает бургомистру на фоне «голых скалистых уступов», обрамляющих его дом (и напоминающих скальный ландшафт оперы). Он обречен на всесветные странствия и - как то происходит с Летучим Голландцем, раз за разом раз его надежда обрести родину оказывается тщетной: «Bom, кажется, я взял разбег, и передо мною уже забрезжили высокие врата но миг - и я очнулся на моем челноке, застрявшем в каких-то унылых водах»; «Челн мой носится без руля по воле ветра, который дует в нижних областях смерти». Подобно Голландцу, Гракх - одновременно и мертвец, и живой, это морской аналог Агасфера. Символизируя участь самого Кафки, вечного чужака и сиониста, так и не обретшего родины, он причислен к душам-призракам, безысходно блуждающим между мирами, что ориентирует его образ в первую очередь на знакомый нам типаж из пьесы Гейне. Процитируем заново исповедь ее героя: «...среди безбрежной водной пустыни, говорит он, плоть его - не что иное, как гроб, в котором тоскует душа; его гонит от себя жизнь и не принимает смерть; подобно пустой

4 Уместно отметить заодно межконфессиональную контаминацию сотериологических мотивов у Кафки. Днем, когда к берегу причаливает бот Гракха, к дому бургомистра с символическим именем Сальваторе - слетается голубиная стая; но еще до того, к полуночи, о прибытии охотника его, причем на человеческом языке, извещает разбудивший его огромный голубь размером с петуха. «Да, — подтверждает герой, — голуби всегда летят передо мной». Налицо соединение евангельского повествования о спустившемся с небес голубе (вдобавок сращенном тут с петухом как вестником Воскресения) и парадигматической историей Ноева ковчега, за которой у Кафки проступает также пророчество Исайи о возвращении евреев с чужбины в Сион: «Кто это летит, как облака и как голуби - к голубятням своим?» В его следующем стихе изображены и «корабли», отовсюду доставляющие изгнанников на родину (Ис. 60: 8-9). Все эти символы спасения, однако, не срабатывают у Кафки - применительно к его герою они даны лишь как тщетные обетования. 
бочке, которую волны кидают друг другу и снова насмешливо отбрасывают, мечется бедный голландеи между жизнью и смертью, и ни та, ни другая не хотят его принять».

Впечатляют вместе с тем и коррективы Кафки к собственно вагнеровскому тексту. Если мореплавателю противостоял там охотник, то в новелле они слились в образ охотника-мореплавателя. Синтез был инспирирован не только романтическим ореолом странствующего зверобоя, но и, возможно, его родством с фигурой охотника-мертвеца: ср. средневековую мифологему «дикой охоты», в германских версиях локализуемой именно в Шварцвальде. В то же время Гракх, горный охотник на серн, несет в себе реминисценцию из бесконечно унылой баллады Н. Ленау «Der ewige Jude», написанной в 1839 г. - в промежутке между гейневским и вагнеровским сочинениями. Ее сюжет представляет собой как бы сон во сне: это пересказ рассказа охотника, который преследуя в горах оленя, повстречался с Вечным Жидом, тщетно мечтающем о могильном покое.

Безотносительно к вагнеровскому либретто некоторые переклички с исходной морской легендой можно заподозрить и в миниатюрной притче Кафки «Рулевой». Сам ее сюжет - о чужаке, захватившем управление кораблем, - был, без всякого сомнения, подсказан автору 6-й книгой «Государства» Платона, где соответствующий эпизод использовался в качестве политического иносказания (488 b-d). Не исключено вместе с тем и типологическое сходство между призрачным экипажем «Летучего Голландца» и матросами у Кафки, которые на негодующие протесты настоящего рулевого реагируют с мертвенно-сомнамбулическим равнодушием: «Что за народ! Думают они о чем-нибудь или только, бессмысленно шаркая, проходят по земле?»

\section{3.}

В России с самого начала $\mathrm{XX}$ века и вплоть до Первой мировой войны популярность Вагнера беспримерно выросла, особенно в символистских и смежных кругах. Эта сторона дела давно (см. уже Дурылин 1914) и настолько изучена, что о ней здесь излишне распространяться. Полезно все же уточнить, что в политическом плане его культ подпитывался более или менее прозрачными черносотенными сантиментами и мессиански-националистическим народолюбием - которые, с подачи Луначарского, после Октября на короткий период сменит народолюбие революционного разлива. Так, страстный вагнерианец Блок, призывавший «слушать «музыку революции», соединил свое давнее, но скрытое черносотенство с радикально революционными взглядами (заметно ослабевшими, впрочем, вскоре после его кратковременного ареста).

Неоромантику Александру Грину экстатическая меломания была решительно чужда, но, очевидно, его тоже не обошла предвоенная мода на Вагнера. Если сама легенда о Летучем Голландце мельком была упомя- 
нута им в 1915 г. в рассказе «Капитан Дюк», то гораздо внушительнее отозвалась она в его прославленной «феерии» Aлье паруса (первое полное издание - 1923). Сюжет наметился в самом конце 1916 года — за пару месяцев до Февральской революции (подробнее о предыстории повести и ее ранних набросках Грин 1965: 427-430; 438-439 (комм. В. Сандлера)). Наверняка не из Гейне, а именно из осевшей в памяти Грина оперы пришла к нему первоначальная - «кроваво-красная» окраска парусов. В тогдашней рукописи незаконченная вещь так и называлась: Красные napyca - но тут необходимо принять во внимание, что бывший социалист-революционер давно и бесповоротно разочаровался в любых революциях. Зарождение фабулы его рассказчик возводил к игрушкам, увиденным в витрине магазина: среди них его восхитил «отлично смастеренный бот с правильно сидящим красным крылообразным парусом». Вскоре в порту, «благодаря солнечному эффекту», он как бы претворился в настоящий морской парус «красный, почти алый». Уже тогда, в этой ранней редакции, писатель заботливо устранял потенциальные ассоциации утилитарно-политического свойства: «Надо оговориться, что, любя красный цвет, я исключаю из моего цветного пристрастия его политическое, вернее, - сектантское значение».

Неудивительно, что потом, после победы ненавистного ему большевизма, он отрекся сразу и от инфернальной символики Вагнера, и от багровой окраски ленинского государства. На слуху была знаменитая, возмутившая многих интеллектуалов, поэма Блока Двенадиать (1918), где прославлялся «мировой пожар в крови» и где отряд большевистских убийц, выступающих под «кровавым флагом», вел сам Иисус Христос, - сочетание, производное, впрочем, от тогдашней религиозно-политической эклектики. В итоге «кроваво-красные паруса» Летучего Голландца перекрасились у Грина в солярно-оптимистический альй цвет, который заодно обезопасил автора и от любых подозрений в заискивании перед властью. Вместе с этим колористическим сдвигом принципиально иное, чем в либретто, распределение и освещение получили ключевые персонажи Вагнера.

Ассоль, героиня феерии, еще в младенчестве утратила мать, и с тех пор ее преданно воспитывает отставной моряк Лонгрен. Это почти соименник вагнеровского Лоэнгрина, но созвучие скорее всего сигнализирует лишь о каких-то неопределенно-оперных привязках Грина, в поле внимания которого здесь находился только «Летучий Голландец», вернее, его либретто. Показательнее оттого ситуативное совпадение: в обоих текстах отец героини - мореход. Правда, в отличие от капитана Даланда, матрос Лонгрен лишен корыстолюбия и принадлежит к числу романтических одиночек - столь же нелюдимых, кстати, как и сам Грин, литературный псевдоним которого тоже кодируется в этом имени (настоящая фамилия писателя - Гриневский). Лонгрена люто ненавидят и боятся филистеры, населяющие соседнюю деревню Каперна. Их растущая враждебность переносится на Ассоль, и та с детства предпочитает социуму мечтательное уединение, высвеченное метафизической перспективой: «Она знала жизнь 
в пределах, поставленных ее опыту, но сверх общих явлений видела отраженный смысл и н о г о порядка».

Отставной матрос Лонгрен, сам воспитывающий и обучающий дочку, рассказывал ей разные морские страшилки - включая легенду о «Летучем Голландце» с его «неистовым экипажем». Чтобы прокормиться, он вырезает из дерева превосходные игрушечные кораблики, которые он сам или его дочь относят в магазин. Однажды для богатого заказчика он изготовил «миниатюрную гоночную яхту» и, за неимением подходящего материала, снабдил ее «парусами из алого шелка». Словом, зачаточный сюжет из первой редакции развивается теперь во всем объеме.

Игрушка очаровала маленькую Ассоль, и по пути в «игрушечную лавку» она настолько залюбовалась ею, что, спустив суденышко в ручей, стала изображать в лицах важный разговор с его «капитаном». Внезапно кораблик, подхваченный течением, стремительно уплывает. Ассоль мчится за ним по лесу - но крошечная яхта исчезает. В отчаянии девочка добирается до устья ручья и там, у самого моря, видит живописного седого незнакомца, который увлеченно разглядывает подобранный им «лесной сюрприз». То был «путешествующий пешком Энгль, известный собиратель песен, легенд, преданий и сказок», выказывающий и сам «склонность к мифотворчеству». Одежда отчасти придает ему «вид охотника». Умиленный самим обликом и беззащитной доверчивостью Ассоль, он выдает себя за «самого главного волшебника» и, возвращая кораблик, сулит ей чудесное будущее: однажды утром «сияющая громада алых парусов белого корабля двинется прямо к тебе <...> Корабль подойдет величественно к самому берегу под звуки прекрасной музыки; нарядная, в коврах, золоте и цветах, поплывет от него быстрая лодка <...> Тогда ты увидишь храброго красивого принца; он будет стоять и протягивать к тебе руки. - “Здравствуй, Ассоль, - скажет он. - Далеко-далеко отсюда я увидел тебя во сне и приехал, чтобы увезти тебя навсегда в свое царство"». Дома девочка, захваченная предсказанием, пересказывает его растроганному отцу - а тот, в надежде на то, что со временем она все забудет, подтверждает: «Будут тебе алые паруса». Пророчество, однако, навсегда западает в ее душу: «Не раз, волнуясь и робея, она уходила ночью на морской берег, где, выждав рассвет, совершенно серьезно высматривала корабль с Алыми Парусами. Эти минуты были для нее счастьем; нам трудно так уйти в сказку, ей было не менее трудно выйти из ее власти и обаяния».

Понятна тут функция Энгля, который, действуя в согласии с сюжетными стереотипами сказок, принимает на себя роль волшебного помощника. Применительно же к гриновской адаптации оперного материала он замещает вагнеровского ангела, закодированного в самом его имени - Энгль.

Разговор отца и дочери подслушал злобный бродяга - и затем сатирически пересказал его в трактире Каперны, попутно переврав непонятный ему цвет: «Тебе, говорит, исполнится совершеннолетний год, а тогда, говорит, - специальный красный корабль...». Слушатели заключают, что 
«Лонгрен с дочерью одичали, а может, повредились в рассудке», — и местные мальчишки с упоением начинают ее дразнить: «Эй, висельница! Ассоль! Посмотри-ка сюда! Красные паруса плывут!» Так красный цвет, перешедший в повесть из ее дореволюционной редакции, получает в печатном тексте новое и бескомпромиссно отрицательное значение: он всецело знаменует бытовую бесовщину, за которой сквозит презрение к багровой большевистской тирании с ее демагогическим культом «масс». Словом, aлье nаруса Грина решительно противопоставлены вагнеровским кроваво-красньмм парусам.

Прокомментирован был автором и сам этот альтернативный цвет его парусов - «совершенно чистый, как алая утренняя заря, полный благородного веселья и царственности»; «он рдел, как улыбка, прелестью духовного отражения». Колористическая дихотомия настойчиво маркируется под углом приближающегося апофеоза. Будущий «принц» — капитан Грэй однажды случайно подплывает к незнакомой ему деревне, представшей пред ним в красно-инфернальных тонах: «Над краснылм стеклом окон носились искры дылмовых труб: это была Каперна. Грэй слышал перебранку и лай. Огни деревни напоминали печную двериу, прогоревщую дырочками, сквозь которые виден пьлающий уголь».

Сам же Грэй с детства был баловнем в богатом доме, где беззаветно любящая мать с готовностью откликалась на его романтические капризы. Наделенный даром сострадания, фантазией и страстью к приключениям, он грезит о море - и в итоге, сбежав из дома, делается юнгой. Повзрослев и закалившись в суровых испытаниях, он затем осуществил наконец свою детскую мечту — стать капитаном собственного судна. Это трехмачтовый галиот, названный им «Секретом». Поначалу «капитан удивлял матросов капризами неожиданных рейсов, остановок - иногда месячных - в самых неторговых и безлюдных местах, но постепенно и они прониклись «грэизмом» Грэя. Иначе говоря, богатый и мечтательный герой со своей верной командой путешествует, в сущности, бесцельно, хотя при случае охотно перевозит экзотические грузы, включая пряности и «ценные породы деревьев: черное, сандал, пальму. Все это отвечало его аристократизму его воображения».

По отношению к Вагнеру налицо полная реориентация романтических образов, отдающая полемикой с его типажами. Подобно Голландцу, Грэй — морской скиталец, только положительного свойства: это мечтатель. Как и судно Голландца, его корабль гружен ценным добром - но в данном случае это метафора его духовного богатства. И наконец, главное - нарратив о встрече героя с экзальтированной девушкой, доверчиво ожидающей на берегу, возвращен к его романтическим истокам.

Сойдя на землю близ деревни, Грэй бесцельно, казалось бы, блуждает по лесу - и по-романтически «случайно» находит спящую Ассоль. Надев ей на мизинец дорогое старинное кольцо - метку предстоящей встречи, он, не разбудив девушки, уходит в Каперну, где в местном трактире вытя- 
гивает из хозяина историю про «Корабельную Ассоль», как в деревне прозвали «полоумную» фантазерку. Происходит это через семь лет после эпизода с Энглем: напомним о семилетних сроках у Вагнера. Завороженный девушкой и вдохновленный предсказанием, Грэй сразу же решает воплотить его в явь. Отдалившись от Каперны, он тайно убирает прежние паруса на своем «Секрете» и заменяет их альмми.

Наконец обновленный корабль, под звуки, заранее нанятого им оркестра, приблизился к берегу, навстречу бегущей в воде девушке: «От него отделилась лодка, полная загорелых гребцов; среди них стоял тот, которого она, как ей показалось теперь, она знала, смутно помнила с детства». Запыхавшись, она сказала: «— “Совершенно такой” — “И ты тоже, дитя мое! - вынимая из воды мокрую драгоценность, - сказал Грэй. — Вот, я пришел. Узнала ли ты меня?"» Обозначение «драгоценность» отсылает, похоже, к библейской реминисценции из либретто: «высшее сокровище верная жена»; а предписанное каноном взаимоузнавание аранжировано музыкой. Сокровища Голландца трансформировались здесь в роскошное убранство корабля, изображенного плавучим эдемом: палуба «была как небесный сад»; а когда Ассоль вошла в приготовленную для нее каюту, сверху «вновь кинулась огромная музыка» - как гриновский ответ на грохочущую вагнеровскую оперу (и, одновременно, триумфальное завершение романтического «отдаленного зова», ранее тоже доносившегося к Ассоль). Завистливая Каперна посрамлена.

Не забыта Грином и вагнеровская фигура Охотника, только обретающая тут совсем другую, но также важную функцию. Если предсказание об Алых Парусах девочке сделал лишь похожий на охотника Энгль, то уже настоящий - но «неизвестный» - охотник в утренний час с изумлением успел заметить заветный корабль и услышал доносящийся оттуда «внезапный звук» - пение кларнета. Роль благого вестника и свидетеля тут дана как бы в усеченном варианте.

Сказка создана была Грином в отвратительное время, омраченное голодом, беспросветной нищетой и травлей. Для подданных большевизма она была такой же отрадой и выполняла ту же целительную роль, что и оперная музыка.

Александр Грин умер в 1932 году в Крыму от голода. Через несколько десятилетий, после антисталинского ХХ съезда советской компартии (1956), власти решили влить новую кровь в жилы своего дряхлеющего режима, - и стали, посредством комсомола, спешно изобретать «романтику революции», утилизовав для нее Алые паруса. В Комсомольской правде даже появилась рубрика под тем же названием, и до самого конца коммунистического правления гриновскую феерию представляли неким возвышенным иносказанием о большевистской мечте. По сути дела, алые паруса усердно перекрашивали в их изначальный — кроваво-красный цвет. Их почитание среди молодежи успешно поддерживается и сегодня, безотносительно к смене идеологических приоритетов. Но это трагикомическое послесловие к теме уже полностью выходит за ее рамки. 


\title{
КРАТКАЯ БИБЛИОГРАФИЯ
}

Вагнер Рихард. Избранные работыл. Вступ. статья А. Ф. Лосев. Москва: Искусство, 1978. Вагнер Рихард. Кольио Нибелунга. Избранные работы. Сост. и комм. К. Королев. Москва Санкт-Петербург: ЭКСМО-Пресс — Terra Fantastica, 2001.

Гейне Генрих. Собрание сочинений: В 10 т. Т. 5. Из мемуаров господина фон Шнабелевопского. Пер. Е. Лундберга. Ленинград: ГИХЛ, 1958.

Грин Александр. Собрание сочинений. Т. 3. Москва: Правда, 1965.

Дурылин Сергей. Рихард Вагнер и Россия. О Вагнере и будущих путях искусства. Москва: Мусагет, 1913.

Чемберлен Хьюстон Стюарт. Рихард Вагнер. Пред. и пер. с англ. С. Ф. Никитина. СанктПетербург: Владимир Даль ${ }^{5}, 2016$.

Dahlhaus Carl. Richard Wagner's Music Dramas. Trans. by M. Whittall: Cambridge Univ. Press, 1979.

Newman Ernest. Wagner as Man and Artist. London: John Lane, The Bodley Head, 1925.

\section{SHORT LIST OF REFERENCES}

Chemberlen H'yuston Styuart. Rihard Vagner. Pred. i per. s angl. S. F. Nikitina. Sankt-Peterburg: Vladimir Dal', 2016.

Dahlhaus Carl. Richard Wagner's Music Dramas. Trans. by M. Whittall: Cambridge Univ. Press, 1979.

Durylin Sergej. Rihard Vagner i Rossiya. O Vagnere i budushchih putyah iskusstva. Moskva: Musaget, 1913.

Gejne Genrih. Sobranie sochinenij: V 10 t. T. 5. Iz memuarov gospodina fon SHnabelevopskogo. Per. E. Lundberga. Leningrad: GIHL, 1958.

Grin Aleksandr. Sobranie sochinenij. T. 3. Moskva: Pravda, 1965.

Newman Ernest. Wagner as Man and Artist. London: John Lane, The Bodley Head, 1925.

Vagner Rihard. Izbrannye raboty. Vstup. ctat'ya A F. Losev. Moskva: Iskusstvo, 1978.

Vagner Rihard. Kol'co Nibelunga. Izbrannye raboty. Sost. i komm. K. Korolev. Moskva - SanktPeterburg: EKSMO-Press - Terra Fantastica, 2001.

\author{
Михаил Вајскопф \\ РИХАРД ВАГНЕР, ФРАНЦ КАФКА И АЛЕКСАНДАР ГРИН. \\ ИСТОРИЈАТ ЈЕДНОГ ЛИБРЕТА
}

\section{Резиме}

Верзија легенде о Летећем Холанђанину заједно са „крвавоцрвеним једрима“ поморца, на коју је композитора навела Хајнеова проза, претворила се код њега у различите неповезане религиозно-романтичарске клишее, додатно оптерећене позоришним шаблонима. Ову еклетику обједињавао је тек позноромантичарски патос свеопште погибије, којим је либрето прожет. Туђ тужно-ироничном хајнеовском предлошку, али типичан за Вагнеров поглед на свет, обојио је његову агресивну публицистику и преко ње касније нашао практичну реализацију у годинама нацизма. Свог несретног поморца Хајне је упоређивао с Лутајућим Јеврејином Ахашверошем, при чему је овај алегоријски јунак код њега поседовао и национално-аутобиографски подтекст. У својим коментарима уз оперу Вагнер је преузео хајнеовско поређење, али истовремено је у свом памфлету „Јеврејство у музици“ искористио фигуру Ахашвероша у антисемитске сврхе, позивајући на његово уништење. Уз то су

\footnotetext{
5 Добавлю, что это издательство примечательно своими фашизоидными симпатиями.
} 
се у XX веку како либрето, тако и Хајнеова прича, трансформисали код Кафке у новелу „Ловац Грахус“, која такође носи аутобиографски карактер. С друге стране, Вагнерова опера је добила контрастно-позитивно решење у фантазији Александра Грина Гримизна једра, где, између осталог, првобитно „крвавоцрвена једра“ Хајнеа и Вагнера добијају нову нијансу и други соларно-оптимистични смисао.

Кључне речи: Летећи Холанђанин, Хајне, Ахашверош, Кафка, Ленау, Erlösung, Маркс, Грин, поморац, ловац. 